\title{
Sustainable Rural Development Opportunities in Lithuania
}

\author{
Vygandas Kazimieras Paulikas ${ }^{1}$, Imantas Lazdinis ${ }^{2}$ and Algimantas Bakas ${ }^{2}$ \\ ${ }^{1}$ Institute of Political Sciences, Mykolas Romeris University \\ ${ }^{2}$ Institute of Public Administration, Mykolas Romeris University
}

cross $^{\text {ref }}$ http://dx.doi.org/10.5755/j01.erem.66.4.5409

(Received in October, 2013; accepted in December, 2013)

\begin{abstract}
Sustainable development has become the main priority of contemporary global society, and it is increasingly perceived not only in the context of environmental protection, but also as an entirety of processes in ecosystems, the society and different countries.

Ecosystem stability and human well-being in an ecosystem, in the community, the society, and the country are greatly influenced by political, economic, social and cultural processes in the countryside, because rural territories make up a bigger part of the territories of contemporary countries.

The article analyses Lithuanian rural development reviewing the damage done by Russian (Soviet) occupation to the Lithuanian countryside and assessing its development in the context of rural development and contemporary sustainable development in Western European countries and the world. It is concluded that the agricultural model in Lithuania as well as in all other countries that have freed themselves from the Soviet Union is based on Socialist (communist) doctrine and is an extreme contrast to the European Model of Agriculture.
\end{abstract}

Keywords: sustainable development, rural development, stability, ecosystem

\section{Introduction}

Rural and forest ecosystems take up a bigger part of dry land territories of all countries of the world. According to statistical data of the United Nations in 2012 more than half of all inhabitants of the planet lived in rural localities of all countries of the world. Rural inhabitants of developing and less developed countries make up an absolute majority (that often reaches 80-90 per cent) of the whole number of inhabitants of these countries (United Nations Department). A big part of inhabitants, who live in cities in developed countries, have their villas in rural localities and spend most of their free time there or they have established their business enterprises there and spend a lot of work time there.

The European Commission indicates that in $201291 \%$ of the territory of the EU was composed of rural localities, and $56 \%$ of all EU Member State inhabitants lived there (European Commission 2013). Versatile human activities carried out in rural territories have an essential influence on the stability of natural ecosystems and the well-being of each person in them as one component of the ecosystem and the well-being of people as of community members in their own rural communities, societies and countries.

Each year modern farming (ecological, industrial, sustainable etc) and all other human activities in the countryside are increasingly perceived not only as a technical process of production manufacture but also as an entirety of social, cultural, economic and biological phenomena in ecosystems and of human beings in a society. Only with the setting of the industrial society it was understood that without sustainable development, without mutual understanding in the society and trust between different social strata, without the diversity of life species that have formed in ecosystems during the process of evolution and safeguarding of their proportions a real danger arises for the survival of the population of Homo sapiens as a biological species and a social being on the Earth. 
In 1992 global leaders formulated the main provisions of sustainable development of the future world in Rio de Janeiro. From then on sustainable development was legitimised as the main long-term ideology of the development of the global society. In Rio de Janeiro an implementing action plan for sustainable development was passed - "Agenda 21", with goals and means for sustainable development of the global future (UN Department 2013). During the preparation of this extremely important programme the most advanced accumulated global experience (and firstly - the experience of the EU) was used. The beginning of the politics of sustainable development of the European Union is connected with the Environmental Action Programmes that have been prepared since 1972, when the danger of an ecological catastrophe, arising from uncontrolled economic growth with no consideration whatsoever of its effect on the environment, was admitted at the global level. These programmes concentrate on the interaction between economics and the environment. In the Single European Pact passed in 1986 the aim of all countries of the European Economic Community to expand the activities that save natural environment in all areas of activities including agricultural business and other activities in rural territories was confirmed constitutionally (Single European Act 1987). In 2001 in Gothenburg (Sweden) the European Council approved the Sustainable Development Strategy of the European Union, which was renewed and supplemented in 2006 by new provisions that corresponded to topicalities of the times (Sustainable Development Together 2013).

Innovative experience of human activities in natural ecosystems and of harmonious mutual cooperation between separate community members that has formed during centuries in Western Europe determined the appearance of these strategic documents, of EU constitutional legal acts and secondary legal acts on sustainable development important for the European Union and the whole world.

The aim of the work is to assess the peculiarities of Lithuanian rural development in the context of sustainable rural development of Western Europe with regard to the implementation of the principles of sustainable development.

Work methods. This study was conducted according to an analysis of legal acts and other documents, analysis of statistical data, analysis of scientific literature, a comparative historical method and descriptive method.

\section{Demographic changes in the Lithuanian countryside and their impact on sustainable rural development}

Rudiments of the concept of sustainable development, directed towards saving use of natural resources seeking to satisfy increasing use, started forming in the beginning of fast industrialisation when developing economics started to be limited by natural possibilities. Tim Jackson (Tim Jackson 2012) states that: "the vision of social innovation that drives us forward, based on a never ending increase in material wishes, is essentially unsuitable." And the most important thing is that seemingly the cleverest species of the planet - Homo sapiens - is characterised by the increase in those wishes. The thinking of a human being of an industrial society was conditioned by the belief that all economic, social and ecological problems may be solved only by technical means created by people, and the human started to see himself as the Lord on the Earth, who can change ecosystems and human society according to his own whims and wishes. So when talking about the implementation of the concept of sustainable development, firstly we need to keep in mind human activities that need to be regulated in such a way that their negative effect on the environment would be decreased as much as possible. With the current technological development the influence of local communities on the environment is only growing stronger.

The process of property restoration that started after the restoration of independence of Lithuania is connected with the general changes of the number of inhabitants of the country. Undoubtedly rural areas have a great influence on the environment, therefore it is very important to analyse demographic changes happening there. If, based on the data of the Department of Statistics of the Republic of Lithuania (results of the 2011 population census), in 1970 the numbers of inhabitants of urban and rural areas were almost the same (there were 1557.7 thousand of urban inhabitants and 1561.2 thousand of rural inhabitants), so according to the data of the 2011 census already two thirds of all inhabitants lived in cities (66.7\%). Because of unemployment in the countryside most of young rural inhabitants left for cities or emigrated, while mostly people of retirement age were left in rural areas, and they could not farm anymore because of their old age. Besides, although no such data is available, many land and forest owners live in cities and not in places where they have their properties. Some former homesteads have decayed, some others are used only as summer villas, and some buildings are losing their functions. Such a situation does not match the principles of sustainable society development that have been accepted by Lithuania as well.

Although the Law on Land Reform of the Republic of Lithuania that was passed in 1991 after the restoration of independence was oriented towards the restoration of private land property, but in that law, under pressure from the Communist nomenclature of the time, a possibility was left to form big land holdings and agricultural manufacture process based on hired work (Law on Land Reform of the Republic of Lithuania 1991). In 2003 even 36.4\% of crop areas belonged to 1449 farms, and their land areas, covered solely by crops, and exceeded 100 ha, while $11.4 \%$ of crops belonged to 89 farms whose crop areas exceeded 1000 ha (Statistical Yearbook of Lithuania 2004). In 2003 the Law on Acquisition of 
Agricultural Land was passed, which was changed several times, in various periods of time giving the right to farmers to acquire up to $300-500$ ha of agricultural land, and to agricultural companies to acquire up to 500-2000 ha of agricultural land.
According to the law that is in force at the moment farmers and agricultural companies can acquire up to 500 ha of agricultural land (Law on Land Reform of the Republic of Lithuania 2003).

Table 1. Farms according to land areas in ha (2003-2010)

\begin{tabular}{|l|r|r|r|r|r||}
\hline \multirow{2}{*}{$\begin{array}{c}\text { Farm groups according } \\
\text { to land areas in ha }\end{array}$} & \multicolumn{2}{|c|}{ Number of farms } & \multicolumn{2}{c|}{ Land areas in thousands of ha } & $\begin{array}{c}\text { Average farm size } \\
\text { in ha }\end{array}$ \\
\cline { 2 - 6 } & $\mathbf{2 0 0 3}$ & $\mathbf{2 0 1 0}$ & $\mathbf{2 0 0 3}$ & \multicolumn{1}{c|}{$\mathbf{2 0 1 0}$} & \\
\hline In total & 272111 & 199913 & 2835.8 & 3003.6 & 15.02 \\
\hline $0-<1^{*}$ & 283 & 475 & 0.1 & 0.1 & 1.5 \\
\hline $1-<2$ & 20020 & 23312 & 29.8 & 259.2 & 3.4 \\
\hline $2-<5$ & 127905 & 81369 & 398.0 & 306.0 & 7.0 \\
\hline $5-<10$ & & & & 367.5 & 13.8 \\
\hline $10-<20$ & 63247 & 43687 & 438.2 & 201.0 & 24.2 \\
\hline $20-<30$ & 37674 & 26611 & 515.3 & 261.7 & 38.6 \\
\hline $30-<50$ & 10473 & 8308 & 251.5 & 360.9 & 67.8 \\
\hline $50-<100$ & 6641 & 6773 & 249.9 & 327.5 & 137.6 \\
\hline $100-<200$ & 3585 & 5309 & 243.5 & 172.9 & 241.5 \\
\hline $200-<300$ & 1353 & 2380 & 183.6 & 116.7 & 345.3 \\
\hline $300-<400$ & 374 & 716 & 89.2 & 78.3 & 444.9 \\
\hline $400-<500$ & 147 & 338 & 50.5 & 516.8 & 1225.9 \\
\hline$\geq 500$ & 95 & 176 & 42.0 & 344.2 & . \\
\hline
\end{tabular}

Sources: Results of the Agricultural Census of the Republic of Lithuania of 2010. The Department of Statistics of the Republic of Lithuania

It may be seen from the data presented in Table 1 that, disregarding the restrictions for agricultural land foreseen by the laws, a fast process of farms growing bigger is happening in Lithuania. From 2003 to 2010 the number of farms that exceed 500 ha in area increased from 314 to 459 or by 46 per cent, and lands of those farms increased from 516.8 thousand ha to 1 million 225.9 thousand ha or 2.4 times.

According to the data of the 2003 census approximately 1646 ha of land belonged to an average farm of more than 500 ha, and according to the data of the 2010 agricultural census approximately 267 ha of land belonged to one farm of more than 500 ha.

According to the data presented in Table 1 it may be seen that from 2003 to 2010 the number of farms bigger than 400 ha increased from 95 to 176 or almost in double, the number of farms bigger than 300 ha increased from 147 to 338 or more than in double, and the number of farms bigger than 200 ha in that same period of time increased almost in double from 374 to 716 .

According to the data of the 2010 agricultural census published by Eurostat, in all European Union there were $8,919,200$ farmer farms that had $159,875,200$ ha of agricultural land areas. Thus one farm in the whole territory of the EU averagely had almost 18 ha of agricultural land (Agricultural Census 2010). The laws of many EU countries (Denmark, France etc) regulate a lot smaller limits of land ownership than in Lithuania. Unfortunately in Lithuania during the same period of time (from 2003 to 2010) the number of farms that had 20 ha-50 ha agricultural holdings decreased from 17,114 to 15,081 , i.e. the number of farms that dominated in most of other Member States of the European Union decreased. For example, in the beginning of 2012 the agricultural investment company "Agrowill Group" held 32,000 ha of land, out of which 12,800 ha belonged to it as property, while the rest was leased. At the time 400 hired workers worked in the company “Agrowill Group” (Bendrovè Agrowill Group 2013).

It is regrettable that almost all Lithuanian governments after the restoration of independence of 1991 ignored the innovative ideas of the land reform performed in the inter-war Lithuania and were inclined to choose the model of large-scale agriculture based on Socialist (communist) doctrine that did not stimulate sustainability in ecosystems and sustainable society development instead of the European rural development model.

\section{The damage of latifundia farming on agrarian ecosystems}

In 1997 the Luxemburg European Council decided to support the European Model of Agriculture (EMA), determined by harmonious coordination of social, economic and ecological values in all possible ways in all Member States of the European Union. The most important characteristics of this agricultural model are multi-functionality of agricultural activities and multi-sectorial rural development (The European Model of Agriculture 2013).

Inhabitants of European model villages not only take on agricultural, forestry or fishery businesses, but they also actively participate in the protection of natural environment and landscape, they protect ethno-cultural heritage and develop traditional crafts. In such villages family farms of average size are predominant, where all tasks are performed by members of one family, and village communities are 
comprised of members of an abundant middle stratum of the society.

The contraries of the European Model of Agriculture are agriculture based on Socialist (communist) doctrine, collective work, and collective property in big land areas and the Cairns Group latifundia agriculture based on work of a small group of owners and many used hired workers (The Cairns group 2013).

Leaders of South America, Australia and some other countries (Argentina, Australia, Brazil, Chile, Columbia, Canada, Indonesia etc) gathered in 1986 in the city of Cairns in Australia and announced their objectives to pursue their agricultural policies, based only on the theory of comparative advantages and total market liberalisation. The Cairns agricultural model was created and developed in a lot more favourable natural conditions than in Scandinavia and many other European countries. Big private farms (latifundia) are characteristic of this model. Less developed ecological consciousness is typical of their rural communities and genetically modified food technologies dominate in their manufacture process. Expressed wealth inequality of community members with very rich owners of latifundia and their propertyless hired workers is characteristic of such an agricultural model; a lack of ethno-cultural heritage and village culture that has formed in a way of synthesis are noticed there.

The agricultural model based on Socialist (communist) doctrine is an extreme contrast to the European Model of Agriculture. Its ideological basis is the statement that a big collective agrarian company is always superior to a private peasant's farm, and this statement became an undisputed part of the Socialist and later communist - doctrines from the First International Workingmen's Association of 1864 (Rosener V. 2000).

In Lithuania as well as in all other countries that have freed themselves from the Soviet Union the previous rural communist nomenclature and the "new Lithuanians" that were well-disposed towards them became the managers of agricultural companies and managed to acquire a lot more forest and land properties than Lithuanian landlords had owned before the 1919 reform. They also received the bigger part of the support meant for the rural areas by the Lithuanian state and the European Union. Thus a deep social disjuncture remained in the society, mass emigration of exploited and destitute rural inhabitants started, the process of entrenchment of foreign capital of doubtful origin in agriculture and forestry commenced, and other social evils that did not match the National Sustainable Development Strategy were happening and stimulating instability in the country and in ecosystems.

In 2008 after almost two decades after the restoration of the independence of Lithuania Vytautas Landsbergis indicated: "One of the hurting and unhealing problems is malignant, greedy nonrestoration of land to its owners - inheritors. Nonrestoration of land was a continuous resistance to the restoration of forfeit property, for some it was even as revenge for the lost "Soviet power" (Landsbergis V. 2010).

It is obvious that up till now farming in Lithuania is still determined by strong heritage of Socialist (communist) ideology that intertwines with the ideology of latifundia farming of the Cairns group - especially the Latin American example. In both cases the European Model of Agriculture based on family work is eliminated, herewith eliminating the middle stratum of the society, the castes of poor hired workers and rich owners appear in the society, and outcomes of instability (non-sustainability) in the society, the ecosystem and the country related to such social differentiation emerge.

Hanny van Geel, member of the Coordination Committee of the European Coordination Via Campesina that unites 27 farmer organisations from 19 European Member States talked about this in July 2013 at the Meeting of the Chairpersons of the Committees on Rural Affairs that took place in Lithuania. She stated that it was necessary to support sustainable family farms that had to have real possibilities "to live with dignity from their work" (Hanny van Geel 2013).

The latifundia type farming, irrespective of the fact if these latifundia belong to one person or to an agricultural company, not only determine property differentiation of members of rural communities but also very often violate the proportions of life species approved by evolution in rural ecosystems.

In localities where huge field massifs are sowed and planted each year with the same monocultures of crop or planting stock, where big herds of one species of livestock and poultry are formed, people artificially increase the density of the population of one species of plants or trees, livestock or poultry in an ecosystem. Besides, in big land massifs of cultivated land conditions, other species of plants or animals that are interconnected with various relations to grow or exist are not allowed.

Contemporary ecologists have a unanimous opinion that in nature populations of all life species have equal rights to exist, that each of these populations (including disease agents) have functions in ecosystems, entrenched during the evolution process, without which the functioning of ecosystems would be impossible. Also they have indisputably proven than in live nature the population density selfregulating mechanism in ecosystems, entrenched in the long evolution process, is working faultlessly, and it does not allow some populations to overrun others and thus to impoverish the ecosystem diversity that has formed during the evolution process. This natural self-regulating mechanism acts also in monocultures artificially created by people, rarefying them in such a way that a big density of a population of some species would not overrun other populations and would not become the reason for their extinction. During many scientific observations and experiments it was determined that various disease agents play the most important role in this ecosystems' biodiversity selfregulating process. In field monocultures, big herds of livestock and poultry disease agents have especially 
good conditions for circulation and reproduction. Thus people, who want to keep these monocultures of livestock herds, have to defend themselves from these agents, massively using various chemical or biological preparations against them.

The exact amount of life species existing on our planet is not known, and assessments of different biologists on this differ. Currently approximately 1.5 million life forms have been described, and there is a unanimous opinion that approximately 10 million life forms exist on our planet, and half of them are agents of different plant, animal and human diseases (Heywood 1995). It is stated that currently there is nothing more dramatic in the global ecosystems than the ruthless human fight, using the whole power of chemistry and the newest scientific technologies with natural ecosystem self-regulating means, and, first of all, various disease agents in those artificially created ecosystems, where absolute big one population member densities dominate, creating ideal conditions for disease agents to spread and reproduce among members of those populations (Kontrimavičius 1982).

This human fight with nature is becoming the more intensive, the bigger the areas of monocultures become or the more animals are put in herds. This is clearly testified by the yearly increasing scope of the use of pesticides from plant diseases and vermin. According to the National Sustainable Development Implementation Report (2012) the use of pesticides in Lithuania has increased almost two times from 2003 to 2007 (Sustainable Development Strategy Implementation Report of the Republic of Lithuania 2012). As a rule not only the life forms that people are trying to exterminate but also other forms suffer as a result of this fight. The human fight with disease agents in their artificially created monoculture massifs in latifundia and gigantic farms comes back as a boomerang for people with dramatic changes in ecosystems (new species of disease agents appear, human and animal tumorous and allergic diseases start spreading).

\section{The damage of latifundia farming for forest ecosystems and the national landscape}

The forest has always been an integral part of the rural landscape and the whole of life in rural areas. It is not only one of the main sources of food, also for a long time it has been (and in some rural localities it still is) the main source of energy, besides, social functions (the ability to clean air and protect the environment from noise, to generate oxygen, to stabilise and soften the climate) and protective functions of the forest (protection from floods, landslides, soil erosion) are also very important. Also economic importance of the forest cannot be forgotten (production of timber and other forestry products) (Ozolinčius 2005).

According to the data of the National Land Service under the Ministry of Agriculture of the Republic of Lithuania (National Land Service 2013) the general area of forestry land was 1,975,953 ha, which made up $30.3 \%$ of the whole fund of the country's land. Private forestry land made up $34.36 \%$ of all forestry land. Besides, a considerable part $(3.12 \%)$ is taken up by forestry land of legal persons. It is known that legal persons own considerable areas of forests, but they are scattered all through the country, therefore for them the forest is only an object for investing money and a provider of timber. And, as a rule, offices of legal persons are established in cities or bigger settlements, therefore the forest for them is not a necessary landscape element. Although no official data has been published, but it is known that a significant part of forestry land (of course, of agricultural land also) has been bought by various common enterprises established together with foreigners, for which, to be sure, the protection of the national landscape would be the least of their worries.

The current legal system of Lithuania also does not foresee any limits of private forest property, therefore, according to the statistical data, provided by the State Forest Survey Service of the Republic of Lithuania, there are already such private forest properties in Lithuania that exceed 2000 ha. Thus private forests of Lithuania can become the property of several very rich forest owners, and these several owners may dispose of capital resources of foreign countries that are hostile towards the statehood of Lithuania (Paulikas, Lazdinis 2006).

The National Sustainable Development Strategy of Lithuania indicates that 3 equal components form the basis for the concept of sustainable development environmental protection, economic and social development (National Sustainable Development Strategy 2003). It is clear that the current land ownership law in Lithuania forms preconditions for the formation of castes of landowners and people that own very small areas of land, for the deepening of wealth inequality in the society, and for the existence of economically inefficient hired work in agriculture and forestry. Such legal system does not correspond to the provisions set out in the National Sustainable Development Strategy.

Big massifs of cultivated fields distort the previously traditional Lithuanian landscape, which was fragmentary: individual homesteads with cultivated fields, a small body of water, an orchard and a small wood or just a grove not far away. For an owner of such a property the forest was necessary not only as a source of timber that can be cut down and sold for quite a lot of money when it is mature. On October 20, 2010, Lithuania signed the European Landscape Convention that states that "...landscape is a basic component of the European natural and cultural heritage, contributing to human well-being and consolidation of the European identity...", and Member States are obliged to promote landscape protection, management and planning. Besides, Member States that have signed this Convention are obliged to integrate landscape in any other policies with possible impact on landscape (European Landscape Convention 2000). Based on this Convention on December 1, 2004, the Government of the Republic of Lithuania passed an act No. 1526 that 
ratified the Description of the Landscape Policies Directions of the Republic of Lithuania, that states that " landscape is an important territorial resource of the country that encompasses urban and rural territories, forests, waters and fields and that creates conditions for human life and activities, it is the basis of national identity and a component of the quality of life. Landscape protection, management and formation meeting economic, social, cultural, ecological and esthetical social needs are the most important aims of a country" (Description of the Landscape Policies Directions of the Republic of Lithuania 2004). One of the main tasks of the country's landscape policy directions, described in point 19 of this description, is "...to ensure ecological landscape stability, to ensure biodiversity protection and optimal landscape management, to foresee means for protection of historical spatial structures of cultural landscape." Although the Act of the Government of the Republic of Lithuania (On Landscape Policy Implementing Means of the Republic of Lithuania 2004) planned to implement 20 landscape policy implementing means of the Republic of Lithuania, but it planned to prepare and ratify the national level special landscape management plan only in 2012 and to finish the preparation of and to approve the state parks and state reserves' managements plans (planning designs) only in 2013. According to the report presented by the Ministry of Environment on the implementation of these means in 2011 it may be seen that a big part of these means, especially the practical ones, are not implemented giving reasons of economic hardship and lack of resources (Execution of Landscape Policy Implementation Means of the Republic of Lithuania 2011).

Strategic documents of the EU on sustainable development and rural development of recent years, increasingly better ecological education in the EU and in Lithuania, an increasing number of people with higher education in the EU and in Lithuania, and active participation of members of the society in the passing of decisions regarding EU and Lithuanian rural development policies provide good hopes for the future. It leaves to hope that programme documents of the governments of Lithuania will be implemented where aims to develop farming based on family work are declared. In 2008 the programme of the $15^{\text {th }}$ Government of the Republic of Lithuania passed in the Seimas emphasised the following: "We will determine the main directions of rural development, we will prioritise family farming, business and the middle social stratum. We will seek for sustainable rural development" (Programme of the $15^{\text {th }}$ Government of the Republic of Lithuania 2008). Similar aims are declared also in the programme of the $16^{\text {th }}$ Government of the Republic of Lithuania, passed in 2012: "We will support the creation of medium sized commodity and family economies developing a modern competing agricultural, food and forestry economies, using land resources rationally and additionally supporting the development of preserving agriculture and forestry, we will develop economic relations between manufacturers, processors and tradesmen of agricultural products, creating a system that normalises these relations" (Programme of the $16^{\text {th }}$ Government of the Republic of Lithuania 2012). It is probable that at some time in the future real implementation of sustainable rural development policy will take place also in Lithuania instead of just declaring the policy in programmes of Lithuanian political parties and governments of the Republic of Lithuania.

\section{Conclusions}

Having analysed the implementation of the principles of sustainable development in Lithuanian rural development it is possible to state that it is not successful:

1. The on-going demographic processes have determined that unemployment in the countryside forced most of young rural inhabitants to leave for cities or to emigrate, whereas almost only retired people are left in rural areas, who cannot farm anymore due to their old age. Besides, a considerable number of land and forest owners live in cities and not in places where they have their properties. Some former homesteads have decayed, some others are used only as summer villas, and some buildings are losing their functions.

2. Farming in Lithuania is still influenced by a strong heritage of the Socialist (communist) ideology that intertwines with the ideology of latifundia farming of the Cairns group especially the Latin American example, when the European Model of Agriculture based on family work is eliminated, herewith eliminating the middle stratum of the society, the castes of poor hired workers and rich owners appear in the society and outcomes of instability (unsustainability) in the society, the ecosystem and the country related to such social differentiation emerge.

3. The current legal system of Lithuania also does not foresee any limits of private forest property, thus private forests of Lithuania can gradually become the property of several very rich Lithuanian or foreign forest owners, who will not care for the aims of the protection of the national landscape and sustainable rural development.

4. Although Lithuania has signed the European Landscape Convention, but the demographic and land-ownership processes happening in the rural areas do not help protect the national landscape that used to be fragmentary: individual homesteads with cultivated fields next to them, a small body of water, an orchard and a small wood or just a grove not far away. 


\section{References}

Agricultural Census 2010. Online:

http://epp.eurostat.ec.europa.eu/statistics_explained/in dex.php/farm_structure - connected on 09-07-2013.

Company "Agrowill Group". Online:

http://www.agrowill.lt - connected on 08-07-2013.

Dèl Lietuvos Respublikos kraštovaizdžio politikos igyvendinimo priemonių patvirtinimo. LR Vyriausybès 2004 m. gruodžio 1 d. nutarimas Nr. 1526. Online:

http://www.am.lt/VI/index.php\#a/5044 - connected on 09-07-2013.

European Commission. Agriculture and rural development. Online:

http://ec.europa.eu/agriculture/rurdev/index_en.htm connected on 08-07-2013.

Europos kraštovaizdžio konvencija. European Landscape Convention and Explanatory Report. 2000. Lietuvos Respublikos aplinkos ministerija. Online: http://www.am.lt/LSP/files/krast-konv.pdf, connected on 15-08-2013. Online:

Hanny van Geel. Daugiau ūkininku, geresnis maistas.

http://www.lrs.lt/intl/presidency.show?theme=221\&la $\mathrm{ng}=1 \&$ p_sp_reng_id=15 - connected on 01-08-2013.

Heywood V.H. Global Biodiversity Assessment. Cambridge: Cambridge University Press, 1995.

Kontrimavičius V. Parasitizm i evoliucija ekosistem/ ekologičeskije aspekti parazitizma // Žurnal obščej biologii. 1982, p. 291-302.

Landsbergis V. Žmogaus kokybè. Lietuvos teisètvarkos mįslès / Rinkinèlis, ISBN978-609-417-008-9, Vilnius, 2010, p. 53-55.

Lietuvos Darnaus vystymosi strategijos igyvendinimo ataskaita, 2012, p. 46 . Online:

http://www.am.lt/VI/files/0.059407001337582140.pdf - connected on 09-07-2013.

LR kraštovaizdžio politikos igyvendinimo priemoniu vykdymas $2011 \mathrm{~m}$. Online:

http://www.am.lt/VI/index.php\#a/11794.

Lietuvos Respublikos kraštovaizdžio politikos krypčiu aprašas. Valstybès Žinios. 2004, Nr. 174-6443.

Lietuvos Respublikos Žemès reformos istatymas. Valstybès Žinios. 1991, Nr. $24-635$.

Lietuvos Statistikos metraštis 2004, p. 363-373.

Lietuvos Respublikos 2010 metų visuotinio žemès ùkio surašymo rezultatai. Lietuvos statistikos departamentas, Vilnius 2012.

Nacionalinė darnaus vystymosi strategija. LRV 2003 m. rugséjo $11 \mathrm{~d}$. nutarimas $\mathrm{Nr} .1160$.

Nacionalinė žemès tarnyba prie Žemès ūkio ministerijos. Lietuvos Respublikos žemès fondas $2013 \mathrm{~m}$. sausio $1 \mathrm{~d}$. Online:

http://www.nzt.lt/go.php/ - connected on 20-08-2013.

Ozolinčius R. Lietuvos miškai. Vilnius, 2005, p. 125126.

Paulikas V., Lazdinis I. Darni visuomenè - saugus žmogus // Lietuvos Katalikų Mokslų akademijos suvažiavimo darbai, t. XX, 2006, p. 453-466.
Penkioliktos LR Vyriausybès programa. Valstybès Žinios, 2008.12.20, Nr.146, Nr. 5870.

Rosener W. Valstiečiai Europos istorijoje. V.: Baltos lankos. 2000, p.18-19.

Single European Act. OJ 1 169. 19876 29, p. 1 - 28.

Sustainable Development Together for Tomorrow. Online:

http://ec.europa.eu/sustainable/welcome/index_en.htm - connected on 05-07-2013.

Šešioliktos LR Vyriausybès programa. Valstybès Žinios, 2012.12.20, Nr.149, Nr. 7630.

The Cairns group . Online:

http://cairnsgroup.org/Pages/default.aspx - connected on 31-07-2013.

The European Model of Agriculture The Way Ahead. Online:

http://trade.ec.europa.eu/docdib/docs/2005/april/trado c_122241.pdf - connected on 10-07-2013.

Tim Jackson. Gerovè be augimo. Všl Grunto valymo technologijos, Vilnius, 2012, p. 2.

United Nations Department of Economics and Social Affairs. Population division, Population Estimates and Projection Section . Online:

http://esa.un.org/unup/CD-ROM/Urban-Rural-

Population.htm - connected on 08-07-2013.

UN Department of Economics and Social Affairs Division for Sustainable Development http://www.un.org/esa/sustdev/documents/agenda21/index.h $\mathrm{tm}$ - connected on 05-07-2013.

$2011 \mathrm{~m}$. gyventojų surašymo rezultatai. Online:

http://osp.stat.gov.lt/documents/10180/217110/ connected on 29-08-2013.

Prof. habil. dr. Vygandas Kazimieras Paulikas Mykolas Romeris University, Faculty of Politics and Management, Institute of Political Sciences.

Main research areas: Public Policy, Public Administration.

Prof. dr. Imantas Lazdinis - Mykolas Romeris University, Faculty of Politics and Management, Institute of Public Administration.

Main research areas: Environmental Policy and Management, Management of Natural Resources, Sustainable Development Management and Administration, Forest Policy and Management.

Address: Ateities str. 20,

LT-08303 Vilnius.

Phone: +370 52714551 ,

e-mail: i.lazdinis@mruni.eu

Doc. dr. Algimantas Bakas - Mykolas Romeris University, Faculty of Politics and Management, Institute of Public Administration.

Main research areas: Environmental Policy and Management, Sustainable Development Management and Administration. 


\title{
Darnaus kaimo vystymo galimybès Lietuvoje
}

\author{
V. K.Paulikas', I. Lazdinis ${ }^{2}$, A. Bakas ${ }^{2}$ \\ ${ }^{1}$ Politikos mokslu institutas, Mykolo Romerio universitetas, Lietuva \\ ${ }^{2}$ Viešojo administravimo institutas, Mykolo Romerio universitetas, Lietuva
}

(gauta 2013 m. spalio mén.; atiduota spaudai 2013 m. gruodžio mèn.)

Darnus vystymasis tapo pagrindiniu šiuolaikinès pasaulio visuomenès prioritetu ir vis labiau suvokiamas ne vien tik aplinkos apsaugos kontekste, bet ir kaip procesu ekosistemose, visuomenèse, valstybėse visuma.

Ekosistemos stabilumui ir žmogaus savijautai ekosistemoje, savo bendruomenèje, visuomenèje ir valstybèje didžiausią ịtaką daro politiniai, ekonominiai, socialiniai, kultūriniai procesai kaime, nes kaimiškos teritorijos užima didžiają dali šiuolaikinių valstybių teritorijų.

Straipsnyje nagrinejama Lietuvos kaimo plètra, apžvelgiant sovietinès okupacijos padarytą žalą Lietuvos kaimui ir ịvertinant jo plètrą Vakarų Europos valstybiu kaimo plètros ir šiuolaikinès pasaulio darnaus vystymosi kontekste. Remiantis straipsnyje atlikta analize, daroma išvada, kad Lietuvoje, kaip ir kitose posovietinėse šalyse, žemès ūkio modelis yra grindžiamas socialistine (komunistine) doktrina ir visiškai skiriasi nuo europinio žemès ūkio modelio. 